\title{
BULLETIN
}

\author{
OF
}

\section{ENTOMOLOGICAL RESEARCH}

ISSUED BY THE COMMONWEALTH

INSTITUTE OF ENTOMOLOGY

EDITOR : THE DIRECTOR

VOL. 53

(1962)

\begin{abstract}
LONDON :
Commonwealth INSTITUTE of ENTOMOLOGY,

56, QuEEN's GaTe, S.W.7

1963
\end{abstract}




\section{Commonwealth Agricultural Bureaux}

\section{EXECUTIVE COUNCIL}

W. A. C. Mathieson, C.M.G., M.B.E., Chairman, Dependent Territories

H. E. Seneviratne, Vice-Chairman, Ceylon

W. G. Alexander, C.B.E., United Kingdom

J. B. Marshall, Ph.D., Canada

P. F. Butler, M.Agr.Sc., Australia

V. Armstrong, Ph.D., New Zealand

A. M. D'Rozario, Ph.D., India

C. K. ReHeem, Pakistan

J. A. Afari, Ghana

ToH CHOR KeAt, Federation of Malaya

IsA ModibBo, Federation of Nigeria

His Excellency the High Commissioner for Sierra LeONe in the U.K.

G. M. Nhigula, Tanganyika

J. E. C. Coventry, Federation of Rhodesia and Nyasaland

Sir Thomas Scrivenor, Secretary, Farnham House, Farnham Royal, Nr. Slough, Bucks.

\section{COMMONWEALTH INSTITUTE OF ENTOMOLOGY}

\section{Director and Editor}

E. O. Pearson, M.A.

\section{Assistant Director}

R. G. FenNaH, M.A.

Assistant Editor

W. Ruttledge, M.A.

Head Office-c/o British Museum (Natural History), Cromwell Road, London, S.W.7

Publication Office and Library-56, Queen's Gate, London, S.W.7 


\section{CONTENTS}

PAGE

Ashman, F.

Factors affecting the abundance of the copra beetle, Necrobia rufipes

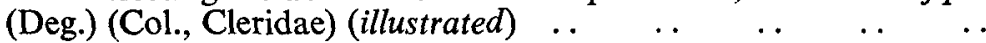

Barlow, F. (see Hadaway, A. B.)

BAR-ZEEv, M.

A rapid method for screening and evaluating mosquito repellents (illustrated)

BenNetT, F. D. (see Manser, P. D.)

BREESE, M. H.

Studies on the oviposition of Rhyzopertha dominica (F.) in rice and

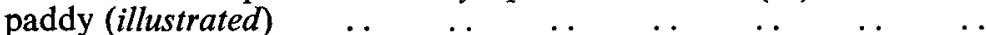

Brown, E. S.

Notes on parasites of Pentatomidae and Scutelleridae (HemipteraHeteroptera) in Middle East countries, with observations on

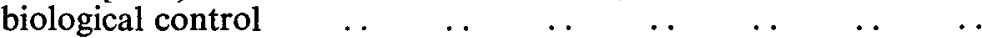

Brown, E. S.

Researches on the ecology and biology of Eurygaster integriceps Put. (Hemiptera, Scutelleridae) in Middle East countries, with special reference to the overwintering period (illustrated) .. . .

BURGES, H. D.

Studies on the Dermestid beetle Trogoderma granarium Everts. V.-Reactions of diapause larvae to temperature (illustrated) . .

BURnetT, G. F.

The susceptibility of tsetse flies to topical applications of insecticides. III.-The effects of age and pregnancy on the susceptibility of adults of Glossina morsitans Westw. (illustrated) $\quad$. $\quad$. . $\quad$..

Burnetr, G. F.

The susceptibility of tsetse flies to topical applications of insecticides. IV.-Wild-caught adults of Glossina swynnertoni Aust. (illustrated)

BURNETT, G. F.

The susceptibility of tsetse flies to topical applications of insecticides. V.-Young adults of Glossina morsitans Westw. and some substituted N-methyl carbamates (illustrated) $\ldots$.

BURNETT, G. F.

The susceptibility of tsetse flies to topical applications of insecticides. VI.-Data on more chlorinated hydrocarbons and organophosphates, and a general discussion (illustrated) .. .. .

Busvine, J. R. \& Townsend, M. G.

The significance of BHC degradation in resistant house-flies 
Carnegie, A. J. M.

Woolly aphid of apple, Eriosoma lanigerum (Hsm.), and its control in Southern Rhodesia (illustrated)

Cole, J. H.

Hofmannophila pseudospretella (Stnt.) (Lep., Oecophoridae), its status as a pest of woollen textiles, its laboratory culture and susceptibility to mothproofers $\quad \ldots \quad$.

Coluzzi, M. \& Contini, C.

The larva and pupa of Mansonia (Coquillettidia) buxtoni (Edwards),

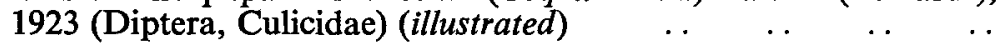

Contini, C. (see Coluzzi, M.)

CORBET, P. S.

The age-composition of biting mosquito populations according to time and level: a further study (illustrated) $\quad . . \quad \ldots \quad \ldots$

Crosskey, R. W.

A new species of Actia R.-D. (Diptera, Tachinidae) parasitic on the coconut leaf moth, Agonoxena pyrogramma Meyrick, in New Britain (illustrated)

DAvid, W. A. L. \& Gardiner, B. O. C.

Oviposition and the hatching of the eggs of Pieris brassicae (L.) in a laboratory culture (illustrated)

David, W. A. L. \& Gardiner, B. O. C.

Observations on the larvae and pupae of Pieris brassicae (L.) in a

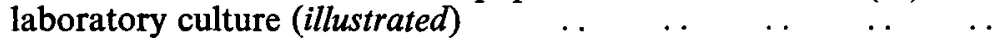

Dudley, B., Gregory, G. E. \& Payne, D. W.

An all-metal cage for rearing locusts in the laboratory (illustrated)

Duncan, J. (see Hadaway, A. B.)

FenNaH, R. G.

Nutritional factors associated with seasonal population increase of cacao thrips, Selenothrips rubrocinctus (Giard) (Thysanoptera), on cashew, Anacardium occidentale (illustrated) $\quad$. $\quad \ldots \quad \ldots$

FENNAH, R. G.

The species of Pyrilla (Fulgoroidea: Lophopidae) in Ceylon and India (illustrated)

Fernando, H. E. (see Wickramasinghe, N.)

Gardiner, B. O. C. (see DAVID, W. A. L.)

GHAuri, M. S. K.

Distinctive features and geographical distribution of two closely similar pests of cotton (Empoasca devastans Dist. and E. terraereginae Paoli) (Homoptera, Cicadellidae) (illustrated)

Glasgow, J. P. \& Welch, J. R.

Long-term fluctuations in numbers of the tsetse fly Glossina swynnertoni Austen (illustrated) 
HARRIS, K. M.

HARRISON, I. R.

Population studies on the poultry red mite Dermanyssus gallinae (Deg.) (illustrated)

Haydock, K. P. (see Stone, B. F.)

HeATHCOTE, G. D. \& WARD, J.

The effect of DDT on Myzus persicae (Sulz.) and Brevicoryne brassicae (L.) (Aphididae) in relation to the spread of cauliflower mosaic and cabbage black ring spot viruses

Hinckley, A. D.

Lepidopterous leafminers on sweet potato in Fiji $\quad \ldots \quad$.

Howe, R. W.

The effects of temperature and humidity on the oviposition rate of Tribolium castaneum (Hbst.) (Coleoptera, Tenebrionidae)

Hussain, Ali A.

Biology and control of the dubas bug, Ommatissus binotatus lybicus de Berg. (Homoptera, Tropiduchidae), infesting date palms in Iraq (illustrated)

JEPSON, W. F. (see Southwood, T. R. E.)

JORDAN, A. M.

The ecology of the fusca group of tsetse flies (Glossina) in southern $\begin{array}{llllllll}\text { Nigeria (illustrated) } & \ldots & \ldots & \ldots & \ldots & \ldots & \ldots & \ldots\end{array}$

JoRDAN, A. M.

The pregnancy rate in Glossina palpalis (R.-D.) in southern Nigeria (illustrated)

Laurence, B. R., Page, R. \& Smith, S. A.

Laboratory colonisation of Mansonia mosquitos

LEFKOVITCH, L. P.

The biology of Cryptolestes capensis (Waltl) (Coleoptera, Cucujidae) (illustrated)

Leggate, B. M. (see Pilson, R. D.)

MacCuaig, R. D.

The collection of spray droplets by flying locusts (illustrated)

MacCuaig, R. D.

The toxicity of some insecticidal sprays to adult locusts (illustrated)

Manser, P. D. \& BennetT, F. D.

Possible effects of the application of malathion on the small moth borer, Diatraea saccharalis (F.), and its parasite Lixophaga diatraeae (Tns.) in Jamaica

MukerJeA, T. D.

New acaricides for control of the red spider mite, Oligonychus coffeae (Nietner), on tea

Page, R. (see Laurence, B. R.)

PARR, H. C. M.

Studies on Stomoxys calcitrans (L.) in Uganda, East Africa. II.Notes on life-history and behaviour .. $\quad \ldots \quad \ldots \quad \ldots \quad \ldots$

Payne, D. W. (see Dudley, B.) 
Pilsov, R. D. \& Leggate, B. M.

A diurnal and seasonal study of the feeding activity of Glossina

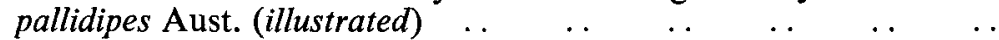

Pilson, R. D. \& Leggate, B. M.

A diurnal and seasonal study of the resting behaviour of Glossina

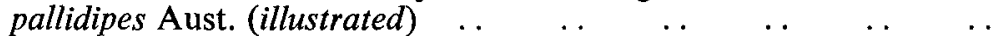

Pleasance, H. J. (see Southwood, T. R. E.)

Proctor, J. H.

The biology and control of the Sudan bollworm, Diparopsis watersi (Roths.), in the Abyan Delta, West Aden Protectorate .. ..

REID, J. A.

The Anopheles barbirostris group (Diptera, Culicidae) (illustrated)

SANDS, W. A.

The evaluation of insecticides as soil and mound poisons against termites in agriculture and forestry in West Africa (illustrated) . .

SAUNDERS, D. S.

Age determination for female tsetse flies and the age compositions of samples of Glossina pallidipes Aust., G. palpalis fuscipes Newst.

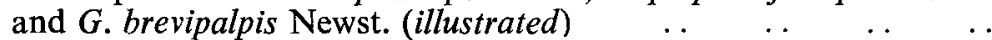

Smith, S. A. (see LaURENCE, B. R.)

Southwood, T. R. E. \& JePson, W. F.

The productivity of grasslands in England for Oscinella frit (L.) (Chloropidae) and other stem-boring Diptera (illustrated) ..

Southwood, T. R. E. \& Pleasance, H. J.

A hand-operated suction apparatus for the extraction of arthropods from grassland and similar habitats, with notes on other models (illustrated)

Ssenkubuge, Yovani (see Haddow, A. J.)

STERnBerG, S. \& TAHORI, A. S.

Control of Aleuroglyphus ovatus (Troupeau) in flea cultures

Stone, B. F. \& Haydock, K. P.

A method for measuring the acaricide-susceptibility of the cattle tick Boophilus microplus (Can.) (illustrated)

TAHori, A. S. (see Sternberg, S.)

Townsend, M. G. (see Busvine, J. R.)

Ward, J. (see Heathcote, G. D.)

Welch, J. R. (see Glasgow, J. P.)

Wickramasinghe, N. \& Fernando, H. E.

Investigations on insecticidal seed dressings, soil treatments and foliar sprays for the control of Melanagromyza phaseoli (Tryon) in Ceylon (illustrated)

WILKINSON, W.

Dispersal of alates and establishment of new colonies in Cryptotermes havilandi (Sjöstedt) (Isoptera, Kalotermitidae) (illustrated). . . .

WooD, R. J.

Oviposition in DDT-resistant and susceptible strains of Aedes aegypti (L.): time from blood-meal to oviposition (illustrated) .. . 
Wood, R. J.

Oviposition in DDT-resistant and susceptible strains of Aedes aegypti

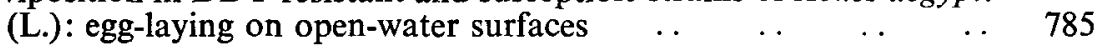
WOODROFFE, G. E.

The status of the foreign grain beetle, Ahasverus advena (Waltl) (Col., Silvanidae), as a pest of stored products $\quad \ldots \quad \ldots \quad \ldots \quad \ldots$

\section{Dates of Publication in Parts}

$\begin{array}{lll}\text { Part I pp. 1-213 } & \ldots & \text { 2 May } 1962 \\ \text { Part II pp. 215-443 } & \ldots & \text { 31 July } 1962 \\ \text { Part III pp. 445-608 } & \ldots & \text { 25 October } 1962 \\ \text { Part IV pp. 609-790 } & \ldots & \text { 17 January } 1963\end{array}$

Vol. 52

\section{ERRATA}

Page 536, Table IV, column 5, for " $0.0050-0.0077$ " read " 0.00050-0.00077" Page 602, Table I, line 2, for " I + II " read " III + IV" and vice versa

\section{Vol. 53}

Page 86, footnote to Table I, for "Dielmoth $=25$ per cent. dieldrin" read "Dielmoth $=20$ per cent. dieldrin"

Page 88, paragraph 4, line 2, for "Dielmoth (25 per cent. dieldrin)" read "Dielmoth (20 per cent. dieldrin )"

Page 145, fig. 3, for " $S$. botanephaga" read " $S$. $n$. botanephaga"

Page 191, paragraph 4, line 3, for " Eucalyptus camaldunensis" read " Eucalyptus camaldulensis"

Page 242, Table I, 1st column, for “ Helomyia ateralis (Mg.) " read “ Helomyia lateralis (Mg.)"

Page 298, line 3, for "West Africa (2) and Haiti " read "West Africa (2) and U.S.A."

Page 334, line 12, for " $1958-59$ " read " $1957-58$ " 